\title{
Building Inter-firm Collaboration -Evidence from Vietnamese SMEs in Tourism sector
}

\author{
Nguyen Phuc Nguyen \\ University of Economics - The University of Danang \\ $71 \mathrm{Ngu}$ Hanh Son, Danang 511, Viet Nam
}

\begin{abstract}
Inter-firm cooperation has received attention in recent year due to its benefit. However, little has been studied about the way to develop this relationship. In this paper we provide evidence on the development of small and mediumsized enterprises (SMEs) in Vietnam relying on inter-firm relationship. Using a recent national survey in $\mathbf{2 0 1 4}$ for tourism sector, empirical results indicate that trust in partner, along with motivation from relationship, are the main predictor of this relationship. Further, it confirms the positive influence of similarities between partners on inter-firm cooperation. Our empirical results indicate that classical determinants of inter-firm relationship including firm age, firm size, location and the ownership are also important in Vietnam. In addition to the traditional indicators we analyze the effect of government support. Direction from the government contributed significantly to the growth of Vietnamese SMEs by fostering inter-firm cooperation, but the importance of this kind of support may be diminishing as private firms do not seem to benefit from this form of support.
\end{abstract}

Keywords: inter-firm relationship, private, trust, SMEs, Vietnam

\section{INTRODUCTION}

Vietnam has introduced officially the economic renovation (Doi moi) since 1986, but it actually adopted a comprehensive and radical reform package aimed at stabilizing and opening the economy in 1990. A new wave of economic reforms has been stirred up with emphasis on private sector development, further trade and investment liberalization with deeper international economic integration especially since 2006 (joining WTO). It is worth noting that the socioeconomic successes have been significantly attributed from the country's small- and medium-sized enterprises (SMEs). They have contributed 39 percent of gross domestic product (GDP), 32 percent of total investment outlays in 2006 (Ho Sy Hung, 2007). Apart from being a relatively dynamic sector in the economy, SMEs have also played an important role in creating jobs, maintaining high mobility of the labor market, and narrowing development gaps among localities of the country.

Inter-firm relationship especially inter-firm cooperation has been the main focus of interest among academics several years. Scholars have conducted various studies to explain the nature of inter-firm relationship (Anderson \& Narus, 1990; Close \& Kukar-Kinney, 2010; Kennedy et al., 2001; Morgan \& Hunt, 1994; Nguyen \& Rose, 2009; Nguyen, 2011). Moreover, the relationship between entrepreneurship and its context has been one of primary concern. It has been argued that the environmental context may have a significant impact on entrepreneurship as well as SMEs development (Antoncic \& Hisrich 2000; Acs et al., 2008; Boettke \& Coyne 2009). Therefore, strengthening SMEs networking with other stakeholders and developing this relationship have long been considered as an effective way to enhance 
SMEs competitiveness or capability. Nevertheless, Vietnamese SMEs networks are still limited. Primary assessment suggests that, apart from weak internal networks, there has been not yet a close link between dynamic multinational corporations (MNCs) and non-integrated domestic SMEs (Ho Sy Hung, 2007) and upstream and downstream industries (Vo Tri Thanh \& Le Xuan Sang, 2004).

There is much to be learned about inter-firm cooperation. To the author knowledge, managing inter-firm relationships is the most difficult work. On the one hand, managers have for years been making great effort to generate competitive advantage in their business units, but it is much more difficult for a single business today to create and maintain a sustainable competitive advantage. On the other hand, the traditional relationship characterized by price focus, competitive bidding, and short- term contracts has given way, at least in part, to closer and more collaborative relationships characterized by long term focus, mutual trust, mutual dependence, and cooperation (Spekman, 1988). In addition, a large fraction of the cooperative ventures falls short of expectations (Harigan, 1985). Therefore, the study tries to build up SMEs network based on investigating determinants of this relationship. Using SME enterprises in Vietnam, the study revealed the determinants of inter-firm relationship.

We start with the conceptual foundations for this paper and review the current literature of inter-firm collaboration in inter-firm relationships. We then develop hypotheses on inter-firm collaboration. Then the study presents a discussion of the methods, data analyses and results. A discussion on findings and practical implications concludes our paper.

\section{BACKGROUND AND HYPOTHESES}

Inter-firm relationships develop from interactions between firms as they exchange goods, services, and knowledge. Oliver (1990) describes inter-organizational relationships as the relatively enduring transactions, flows, and linkages that occur among or between organizations. Inter-firm relationships have the three distinctive types: pure cooperation, pure competition, and coopetition (Galvagno \& Garraffo, 2010). Cooperation occurs when firms or groups act together in a coordinated way to pursue shared goals, enjoy an activity, or simply further their relationship (Argyle, 1991). Cooperation is a specific type of inter-firm relationships, which shows a shared interest of working together towards a mutual goal. Cooperation refers to a process, while cooperative alliances refer to the forms (Gray \& Wood, 1991). Cooperation also infers that one party gives up some immediate benefits in the hope of receiving a later payoff (Palmer, 2000). The common goals are more important than one actor's profit maximization or opportunism. Partners contribute to the total created value in the relationships, and they are satisfied with a smaller share of the profit to maintain the relationship (Bengtsson \& Kock, 2000). Moreover, inter-firm collaboration is not automatic since it is not in the players' interest to behave cooperatively if there are no guarantees that each player will reciprocate (Gibbons, 1992).

\section{Relationship between manager's trust and inter-firm collaboration}

Anderson and Narus (1990), defined trust as the firm's belief that another company will perform actions that will result in positive outcomes for the firm, as well as not take unexpected actions that would result in negative outcomes for the firm. The proposed link between trust in the selling firm and the buyer's future purchase intentions also reflects that buyers can rely on the integrity of suppliers they trust. According to Ganesan (1994), trust is a necessary ingredient for long-term orientation because it shifts the focus to future conditions. Empirical evidence supports the notion that trust of the selling firm is central to a buyer's intention to continue the exchange relationship. Anderson and Weitz (1989) find evidence that 
trust is key to maintaining continuity in conventional channel relationships. Morgan and Hunt (1994), based on relationship marketing research, confirmed that trust and relationship commitment are the two important elements in fostering cooperation between partners. The similar result also is displayed in recent article when Lui et al. (2006) found that trust has an important role in cooperative behavior. Therefore, we propose the following:

H1: Firm trust in partner is positively related to future interaction with that partner.

\section{Relationship between expectation from inter-firm cooperation and inter-firm collaboration}

The current literature on inter-firm relationships and technology acceptance highlights the importance of motivation for behavior. They can be expectation of success (Bagozzi \& Warshaw, 1990), perceived usefulness (Davis, 1986), and relationship benefit (Morgan \& Hunt, 1994). Firm can engage in inter-firm relationship in order to achieve specific goals/rewards (Huybers \& Bennett, 2003; Nguyen, 2011) or perceived desirability (Krueger et al., 2000).

Organizations will build the relationship with other parties when cooperation per se takes on a positive value. Evan (1965) suggested that value expectancy will pull organizations into cooperation. A feeling that cooperation is substantially good may stimulate firms to move in the direction of inter-firm cooperation (Schermerhorn, 1975). Morgan \& Hunt (1994) and Friman et al. (2002) revealed that firms that receive superior benefits from partnership will commit themselves into this type of relation. The expectation from inter-firm relationship can stimulate manager's intention to make cooperation with its partner even if they do not possess a positive attitude toward partner or partner's representatives (Nysveen et al., 2005; Nguyen, 2011). Thus,

H2. There is a positive relationship between expectation from inter-firm relationship and inter-firm cooperation

\section{Relationship between entrepreneurial intensity and inter-firm collaboration}

Corporate entrepreneurship is a process by which individuals inside organizations pursue opportunities without regard to resources they currently control (Stevenson \& Jarillo-Mossi, 1990). Entrepreneurial intensity is characterized by degree and frequency entrepreneurship. Miller and Friesen (1982) argue entrepreneurial firms are characterized by their strong willingness to innovate while taking risks in the process. In addition, through the strategic decision making process where entrepreneurs are willing to take risks, innovative, and proactive, entrepreneurial intensity will facilitate the solving management problems (Barringer \& Bluedorn, 1999).

In competitive environment, many organizations commonly acquire ideas or innovations internally. However, there are a number of situations where some organizations seek innovative ideas externally in form of franchising, sub-contracting and strategic alliances. As a means of partial uncertainty absorption, entrepreneurial intensity in the form of environment scanning may lower the perception of risk associated with a potential entrepreneurial venture, increasing the likelihood that the firm will engage in the venture (Barringe \& Bluedorn, 1999). Thus, the study expects that:

H3. There is positive relationship between entrepreneurial intensity and inter-firm collaboration. 


\section{Relationship between regulation and inter-firm collaboration}

Many writers have studied the effect of active public policy on promoting cooperation among businesses. In most developed economy, the government issued local, regional and national policy with the aim at fostering inter-firm cooperation. Rosenfeld (1996) exhibited the efficiency of public program in Denmark. By making a large investment to the support-called program over finite of time, the government hoped that by proving the value of networks, cooperative behavior would become absorbed into the culture. The reasonable object of such programs is to help firms to get the effect of economy of scale, compete better in global market (Arku, 2002). In addition, Kipping (1996) from studying the connection between inter-firm relationships and industrial policy, showed that the governmental policies have important role for the success of French industry. Adobor (2006) cited that the government can facilitate cooperation between companies as the role of third party. By encouraging building business development services and the formation of the agency for SMEs development, the government can provide needed information to companies (Cho \& Yu, 2000; Tran et al., 2009, Nguyen, 2011). Moreover, by issuing rule on specific issue, Chinese government has fostered corporations within industrial chain to in carbon emission reduction (Zhang \& Wang, 2014). Based on these results, we form the following hypothesis:

H4. There is the positive relationship between regulation and inter-firm cooperation.

\section{Relationship between similarities between partners and inter-firm collaboration}

A company will not success in managing alliance if it does not understand its partner. The relatively similarity between partners reduce the incentives for free riding and enhances the possibility of inter-firm cooperation (Huyber \& Bennett, 2003). Similarities between partners can shape inter-firm relationship and cooperative behaviour because they can facilitate the articulated knowledge among firms (Teece, 1977; Saxton, 1997). In addition, it can help partners build inter-firm trust and inter-firm cooperation as the result. When firms are similarity in strategic decision and culture, they can get along with its partner. Moreover, similarities between partners lead to balanced inter-firm power relationship and impact to level of cooperation in the network-firm (Chassagnon, 2014). From the survey of SME tourism enterprises in Vietnam, Nguyen (2015) confirmed that similarities among partner who involve in tourism network will enhance the chance of inter-firm relationship. Therefore, we expect that:

\section{METHOD}

\section{Data}

To examine the hypotheses empirically, we conducted a mail survey of SMEs in tourism industry in 2014. The questionnaire we designed included three parts. The first part consisted of demographic questions, including corporate ownership structure, the number of employees, age, etc. The second part related to inter-firm relationship. The last part asked the respondents about performance and achievements. The questionnaire firstly developed in English and then translated into Vietnamese. A pilot test was undertaken with 30 managers and seniors who were taking MBA program at a major research university in Vietnam.

The sampling frame consisted of 600 companies listed by the Yellow page in Vietnam. To examine the factors promoting inter-firm collaboration, we narrowly defined the observations by excluding respondents that did not answer the question or not complete. As a result, 262 of the observations were utilized for the econometric analysis. 
Because this detailed survey is used for many purposes in our studies, the authors only specify the information that is directly used for this paper. From the survey, the majority of participating firms are small size that has less than 200 full-time employees, covers $66.52 \%$ of the survey (medium size: 25.21\% and large size: $8.27 \%$ ). This can be because of Vietnamese still being transition economy. Moreover, about more than half of the enterprises originated from private and foreign sector and are relatively young.

\section{Measures}

\section{Dependent and independent variables}

The measurement scale development was adapted from literature. All items were assessed on seven-point Likert type scale anchored by 1 (strongly disagree) and 7 (strongly agree). The detail is shown in the table 1.

Table 1: Measurement items and resources

\begin{tabular}{|c|c|c|}
\hline Constructs & $\begin{array}{l}\text { Number } \\
\text { of items }\end{array}$ & Sources \\
\hline $\begin{array}{ll}\text { Expectation } & \text { form } \\
\text { cooperation (MC) } & \end{array}$ & 5 & $\begin{array}{l}\text { Johnson \& Sohi (2001), Stank et al., (2001) and } \\
\text { Kim et al. (2012). }\end{array}$ \\
\hline $\begin{array}{l}\text { Similarity between partner } \\
\text { (SP) }\end{array}$ & 6 & Saxton (1997) and Adobor (2006). \\
\hline $\begin{array}{l}\text { Entrepreneurial intensity } \\
\text { (EI) }\end{array}$ & 3 & $\begin{array}{l}\text { Covin and Miles (1999), Barringer \& Bluedorn } \\
\text { (1999). }\end{array}$ \\
\hline Regulations (RE) & 4 & Nguyen (2011); Zhang \& Wang (2014) \\
\hline Trust in partner (TP) & 3 & Doney \& Cannon (1997); Ryu et al (2011). \\
\hline Inter-firm collaboration (IC) & 3 & $\begin{array}{l}\text { Vereecke \& Muylle (2006); Zhang \& Wang } \\
\text { (2014); }\end{array}$ \\
\hline
\end{tabular}

\section{Control variables}

Company characteristics have been proved to have significant impact on cooperation behavior and that were controlled for the empirical analysis. They conclude establishment size (measured by number of employee), type of sector, and age of company. According to Fritsch \& Lukas (2001), firms are engaged in $R \& D$ cooperation, tend to be large. The positive effect of firm's size on inter-organization cooperation in R\&D field can also be found in number of works (Fritsch, 2003; Okamuro, 2007). On the contrary, Felzenstein \& Gimmon (2007) found the negative effect of size on inter-firm relationship. The second control variable relates to ownership. The dummy variables, which value 1 if firm is owned by specific subject (state, private or foreign owned) are added, respectively. Executives of particular type of ownership likely have different objectives and attitudes toward inter-firm relationship (Nguyen \& Rose, 2009; Nguyen, 2011).

The region where the company locates has influenced inter-firm relationship. This will shape the attitude of company's managers toward this relationship. Fritsch \& Lukas (2001) and Fritsch (2003) revealed the significant differences in cooperation among regions with regard to the propensity to maintain a cooperative relationship. Based on Vietnamese context, the south will prefer cooperation than the north due to the western influence as the result of market-based experience compare with the bureaucracy-rooted economy in the north (Tran et al., 2009). 


\section{Empirical model}

The study aims to test the impacts of determinants of inter-firm relationship on the level of cooperation of these relationships. We use inter-firm collaboration to demonstrate external collaboration among partner in the tourism value chain. The empirical model is that:

$\mathrm{IC}_{\mathrm{i}}=\alpha+\varphi \mathrm{MC}_{\mathrm{i}}+\chi \mathrm{SP}_{\mathrm{i}}+\gamma \mathrm{EI}_{\mathrm{i}}+\kappa \mathrm{RE}_{\mathrm{i}}+\lambda \mathrm{TP}_{\mathrm{i}}+\eta \mathrm{X}_{\mathrm{i}}+\tau_{i}$

Where $\mathrm{Xi}$ is controlling vector; and $\varepsilon \mathrm{i}$ is the error term

\section{Construct validity}

\section{RESULTS}

Each variable measured with multiple items was subjected a scale development procedure. We conducted exploratory factor analysis for each set of construct. We then checked for satisfactory reliability. End of this step, two items were dropped due to low factor loading. We then conducted confirmatory factor analysis using LISREL 8.80 with the maximum likelihood method to evaluate the convergent and discriminant validity of the measures. Table 21 provides the results of the measurement analysis. Result indicated a statistically significant ( $\chi^{2}=267.51, d f=174, p=.00, \mathrm{GFI}=0.91, \mathrm{CFI}=0.90$ and RMSEA=0.067). The result indicated that all constructs have adequate internal consistency with Cronbach's alpha ranging from 0.76 to 0.90 , ensuring adequate internal consistence of multiple items of each construct (Hair et al., 2009).

Table 2: Convergent and discriminant validity assessment

\begin{tabular}{|l|c|c|c|c|}
\hline Constructs & $\begin{array}{c}\text { Number of } \\
\text { items } \\
\text { (remain) }\end{array}$ & $\begin{array}{l}\text { Cronbach } \\
\text { alpha }\end{array}$ & AVE & $\begin{array}{l}\text { Item } \\
\text { dropped }\end{array}$ \\
\hline $\begin{array}{l}\text { Expectation form cooperation } \\
\text { (MC) }\end{array}$ & 4 & 0.87 & 0.59 & 1 \\
\hline Similarity between partner (SP) & 5 & 0.90 & 0.64 & 1 \\
\hline Entrepreneurial intensity (EI) & 3 & 0.89 & 0.58 & \\
\hline Regulations (RE) & 4 & 0.76 & 0.52 & \\
\hline Trust in partner (TP) & 3 & 0.85 & 0.50 & \\
\hline Inter-firm collaboration (IC) & 3 & 0.88 & 0.63 & \\
\hline
\end{tabular}

To test convergent validity, we checked the value of AVE and CR (construct reliability). The average percentage of variance extracted (AVE) for all constructs were greater than 0.50, suggesting adequate convergence (Fornell \& Larcker, 1981). Moreover, construct reliability of all construct pass the threshold of 0.7 for good reliability (Hair et al., 2009). Therefore, the result indicates good discriminant validity of the model.

\section{Hypotheses tests}

Following Van Bruggen et al. (2002), the study adapts a confidence-based weighted mean to obtain construct scores. The single overall confidence score, which is standardized loading, applies for the type of weight. We tested our hypotheses using maximum likelihood estimation by STATA 13 package. To check for multicollinearity, we examined the VIF test. In our regression, the highest VIF value was 1.78 . This confirmed that multicollinearity was not a problem. The result was show in table 3.

The first model only includes the independent variable without controlling vector. It is very important to note that these variables are highly significant. The fact that trust in partner is positively and strongly linked to the probability that the inter-firm relationship is strongly 
cooperative. This variable is positive and significant for all models proposed $(\mathrm{p}<0.01)$. Moreover, trust in partner seems to be the most influence factor for inter-firm relationship. Thus, hypothesis 1 is confirmed. This result is consistent with the previous research findings (Lui et al. 2009; Ryu et al., 2011).

Table 3: Regression result

\begin{tabular}{|c|c|c|c|c|}
\hline \multirow[t]{2}{*}{ Variables } & \multicolumn{4}{|c|}{ Regression results } \\
\hline & Model 1 & Model 2 & Model 3 & Model 4 \\
\hline $\begin{array}{l}\text { Expectation form cooperation } \\
\text { (MC) }\end{array}$ & $1.026 * * *$ & $1.110 * * *$ & $1.105 * *$ & $1.105 * *$ \\
\hline Similarity between partner (SP) & $0.321 * *$ & $0.307 * *$ & $0.389 * *$ & $0.389^{* *}$ \\
\hline Entrepreneurial intensity (EI) & $0.684 * * *$ & $0.724 * * *$ & $0.775 * * *$ & $0.775 * * *$ \\
\hline Regulations (RE) & $0.321^{*}$ & $0.378^{*}$ & $0.327^{* *}$ & $0.327 * *$ \\
\hline Trust in partner (TP) & $1.381 * * *$ & $0.1 .420 * * *$ & $1.657 * * *$ & $1.657 * * *$ \\
\hline Small & & -0.069 & -0.085 & -0.085 \\
\hline Medium & & $0.032 *$ & $0.048^{*}$ & $0.059^{*}$ \\
\hline Private & & & $0.059^{*}$ & $0.046^{*}$ \\
\hline Foreign & & & 0.023 & $0.037 *$ \\
\hline Age & & & No & No \\
\hline Central & & & & Yes \\
\hline South & & & & Yes \\
\hline Constant & Yes & Yes & Yes & Yes \\
\hline R-squared & 0.278 & 0.312 & 0.296 & 0.308 \\
\hline F statistic & $9.012 * * *$ & $11.04 * * *$ & $14.67 * * *$ & $14.67 * * *$ \\
\hline $\mathrm{N}$ & 262 & 262 & 262 & 262 \\
\hline
\end{tabular}

Note: ${ }^{* * *} \mathbf{p}<0.01,{ }^{* *} \mathbf{p}<0.05, * \mathbf{p}<0.1$.

Related to the impact of expectation from inter-firm cooperation on inter-firm collaboration, hypothesis 2 predicts that expectation from inter-firm cooperation has positive relationship with inter-firm collaboration. The coefficient has positive sign and is highly. These results provide support for hypothesis 2. This finding reveals the importance of this element in explaining behaviors across wide range of theories (Armitage \& Conner, 2001; Carr \& Sequeira, 2007, Nguyen, 2015).

Hypothesis 3 states that entrepreneurial intensity is positively associated with inter-firm collaboration. Bases on highly significant evidence in Table 3, the hypothesis is supported. For the Vietnamese context, the attitude of managers toward entrepreneurship will facilitate the building inter-firm relationship due to enhancing risk taking. Hypothesis 4 predicts that regulation is positively related to inter-firm collaboration. It is important to note that this variable is significant. The role of government in shaping industrial relationships by regulation is supported not only in developed countries like French, German, Japan and Korea (Kipping, 1996; Nakamura et al., 1997; Cho \& Yu, 2000) but also in transition economy like Vietnam (Nguyen, 2011).

The similarities between partners has a positive influence on the probability of strong interfirm cooperation. The results also revealed the fact that similarities between partners will facilitate inter-firm cooperation due to reduce free riding among partners. This result also supports for the findings of Saxton (1997) and Nguyen (2015). Hypothesis 5 is thus empirically confirmed. From the result, the difference between regions in inter-firm relationship is 
significantly. Within tourism industry, company in the central and the south are willing to create inter-firm relationship, especially for the private sector. Due to high customer demand and resource base, the private sector is likely to form relationship with its partners.

\section{DISCUSSIONS}

The empirical results from Vietnamese enterprises data above strongly support the proposed hypotheses for inter-firm relationships. Among the determinants, trust in partner plays the most powerful role in facilitating inter-firm relationship. In Vietnamese context, trust between partners (managers or owners) will direct the potential behaviors. Supporting the RBV's argument that it is the use of the resources, rather than their mere existence that bring competitive advantage as well as customer services, this study suggests that one way to enhance company performance by development SMEs network. Company should reconfigure the resources is to external collaborations so that firm can assess and incorporate resources it does not possess. In addition, "preferably" managerial attitude toward entrepreneurship associated with an increased likelihood of inter-firm cooperation. The entrepreneurial intensity also helps us in understanding the reason why trust has been key mediating variable in commitment-trust theory (Morgan \& Hunt, 1994). Fourthly, the results also support the positive effect of regulation on inter-firm relationships. Through management tools such as promulgating an act or publishing policies, government can foster this kind of relationships. Finally, similarity among partners is important factor for building inter-firm relationship.

This study also provides important managerial implications for inter-firm collaboration. First, in order to effectively engage external partners, firms must build and enhance entrepreneurial attitude of its managers. The entrepreurial attitude set the foundation for collaboration. Second, since trust and similarity are very component in inter-firm relationship, firms should evaluate their own capabilities in managing company, leadership style, organizational culture, and relationship. Building some aspects in common, firms will form inter-firm relationship at ease. Third, policy maker should edit the regulation for shaping inter-firm relationship in the way of more efficiently. By this mechanism, government can facilitate this relationship as well as the development of SMEs in Vietnam.

\section{References}

Acs, Z. J., Sameeksha, D., \& Hessels, J. (2008). Entrepreneurship, Economic Development and Institutions. Small Business Economics 31 (3), 219-234.

Adobor, H. (2006). Inter-firm collaboration: Configurations and dynamics. Competitiveness Review: An International Business Journal incorporating Journal of Global Competitiveness, 16, 122-134.

Anderson, E., \& Weitz, B. (1989). Determinant of continuity in conventional industrial channel dyads. Marketing Science, 8(4), 310-323

Anderson, J. C., \& Narus, J. A. (1990). Model of distributor firm and manufacturer firm working partnerships. Journal of Marketing, 54, 42-58. http://dx.doi.org/10.2307/1252172

Antoncic, B., \& Hisrich, R. D. (2000). Intrapreneurship Modeling in Transition Economies: A Comparison of Slovenia and the United States. Journal of Developmental Entrepreneurship 5 (1): 21.

Argyle, M. (1991). Cooperation: The basis of sociability. New York : Routledge

Arku, G. (2002). Collaboration in industry: Empirical findings among small electronics manufacturing firms in the greater Toronto area. GeoJournal, 57(4), 301-312. http://dx.doi.org/10.1023/B:GEJ0.0000007358.00395.0d

Bagozzi, R. P., \& Warshaw, P. R. (1990). Trying to consume. Journal of Consumer Research, 17, 127-140.

Barringe, B. R., \& Bluedorn , A. C. (1999). The relationship between corporate entrepreneurship and strategic management. Strategic Management Journal, 20 (5), 421-444. 
Bengtsson, M., \& Kock, S. (2000). Co-operation in business networks- To cooperate and compete simultaneously. Industrial Marketing Management, 29, 411-426.

Boettke, Peter J., \& Christopher J. Coyne. (2009). Context Matters: Institutions and Entrepreneurship. Foundations and Trends w in Entrepreneurship, 5(3), 35-209.

Chassagnon Virgile (2014). Consummate cooperation in the network-firm: Theoretical insights and empirical findings. European Management Journal, 32(2), 260-274. http://dx.doi.org/10.1016/j.emj.2013.01.002

Cho, D. H., \& Yu, P. I. (2000). Influential factors in the choice of technology acquisition mode: An empirical analysis of small and medium size firms in the Korean telecommunication industry. Technovation, 20, 691-704.

Close, A. G., \& Kukar-Kinney, M. (2010). Beyond buying: Motivations behind consumers' online shopping cart use. Journal of Business Research, 63(9-10), 986-992. http://dx.doi.org/10.1016/j.jbusres.2009.01.022

Covin, J. G., \& Miles, M. P. (1999). Corporate entrepreneurship and the pursuit of competitive advantage.

Entrepreneurship: Theory and practice, $23(4), 47-63$.

Davis, F. D. (1986). A technology acceptance model for empirically testing new end-user information systems: Theory and results. (Doctoral dissertation, Sloan School of Management, Massachusetts Institute of Technology).

Doney, P. M., \& Cannon, J. P. (1997). An examination of the nature of trust in buy-seller relationships. Journal of Marketing, 61, 35-51.

Evan, W. M. (1965). Toward a theory of inter-organizational relations. Management Science, 11, B217-B230.

Felzensztein, C., \& Gimmon, E. (2007). The influence of culture and size upon inter-firm marketing cooperation. A case study of salmon farming industry. Marketing Intelligence and Planning, 25, 377-393.

Fornell, C. and Larcker, D. F. (1981). Structural equation models with unobservable variables and measurement error. Journal of Marketing Research, 18, 39-50. http://dx.doi.org/10.2307/3150980

Friman, M., Gärling, T., Millett, B., Mattsson, J., \& Johnston, R. (2002). An analysis of international business to business relationships based on the commitment-trust theory. Industrial Marketing Management, 32, 403-409.

Fritsch, M. (2003). Does R\&D cooperation behavior differ between regions? Industry and Innovation, 10(1), 25-39. http://dx.doi.org/10.1080/1366271032000068087

Fritsch. M., \& Lukas. J. (2001). Who cooperates on R\&D? Research Policy, Vol. 30, pp. 297-312.

Galvagno, M., \& Garraffo, F. (2010). The promise of coopetition as a stream of research in strategic management. In Dagnino G.B., S. Castaldo, F. Le Roy, and S. Yami (Eds.) Coopetition. Winning Strategies for the 21st Century, Edward Elgar Publishing Cheltenham, UK, pp. 40-57.

Ganesan, S. (1994). Determinants of long-term orientation in buyer-seller relationships. Journal of Marketing, 58, 1-19.

Gibbons Robert (1992). Game Theory for Applied Economists. Princeton, NJ.: Princeton University Press.

Gray, B., \& Wood, D. J. (1991). Collaborative alliances: Moving from practice to theory. Journal of Applied Behavioral Sciences, 27, 3-22.

Hair, J. F., Black, W. C., Babin, B. J., \& Anderson, R. E. (2009). Multivariate data analysis (7th Ed.). Prentice Hall.

Harigan, K. R. (1985). Strategies for joint ventures. Lexington, Mass: Lexington Books.

Ho Sy Hung (2007). Strengthening supporting industries in Vietnam: Linking Vietnamese SMEs into global value chains. Agency for SME Development, Ministry of Planning and Investment, Ha Noi.

Huybers. T., \& Bennett. J. (2003). Inter-firm cooperation at nature-based tourism destinations. Journal of SocioEconomics, 32(5), 571-587. http://dx.doi.org/10.1016/j.socec.2003.08.011

Johnson, J. L., \& Sohi, R. S. (2001). The influence of firm predispositions on interfirm relationship formation in business markets. International Journal of Research in Marketing, 18(4), 299-314.

Kennedy, M. S., Ferrell, L. K., \& LeClair, D. T. (2001). Consumer's trust of salesperson and manufacturer: An empirical study. Journal of Business Research, 51(1), 73-86. http://dx.doi.org/10.1016/S0148-2963(99)00039-9 
Kipping, M. (1996). Inter-firm relations and industrial policy: The French and German steel producers and users in the twentieth century. Business History, 38, 1-25.

Kim, Yong. J., Song, Seokwoo., Sambamurthy, V., \& Lee, Young. L. (2012). Entrepreneurship, knowledge integration capability and firm performance: An empirical study. Information Systems Frontiers, 14(5), 1047-1060. http://dx.doi.org/10.1007/s10796-011-9331-z

Krueger, N. F., Reilly, M. D., \& Carsrud, A. L. (2000). Competing models of entrepreneurial intentions. Journal of Business Venturing, 15(5-6), 411-432. http://dx.doi.org/10.1016/S0883-9026(98)00033-0

Lui, S, S., Ngo, H-Y., \& Hon, A. H. Y. (2006). Coercive strategy in interfirm cooperation: Mediating roles of interpersonal and interorganizational trust. Journal of Business Research, 59(4), 466-474.

http://dx.doi.org/10.1016/j.jbusres.2005.09.001

Lui, S. S., Wong, Y., \& Liu, W. (2009). Asset specificity role in interfirm cooperation: Reducing opportunistic behavior or increasing cooperative behavior? Journal of Business Research, 62, 1214-1219.

Miller, D., \& Friesen, P. H. (1982). Innovation in conservative and entrepreneurial firms: two models of strategic momentum. Strategic Management Journal, 3(1), 1-25.

Morgan, R. M, \& Hunt, S. D. (1994). The commitment-trust theory of relationship marketing. Journal of Marketing, 58(3), 20-38. http://dx.doi.org/10.2307/1252308

Nakamura, M., Vertinsky, I., \& Zietsma, C. (1997). Does culture matter in inter-firm cooperation? Research consortia in Japan and the USA. Managerial and Decision Economics, 18, 153-175.

Nguyen, N. P. (2011). Applying theory of reasoned action to explain inter-firm cooperation: Empirical evidence from Vietnamese enterprises. International Journal of Management \& Information Systems, 15, 61-81.

Nguyen, N. P. (2015). Integrated View of Inter-Firm Cooperation: An Empirical Study in Tourism Region. International Journal of Economics and Finance. 7(8), 77-87.

Nguyen, T. V., \& Rose, J. (2009). Building Trust-Evidence from Vietnamese Entrepreneurs. Journal of Business Venturing, 24, 165-182. http://dx.doi.org/10.1016/j.jbusvent.2008.03.004

Nysveen, H., Pedersen, P. E., \& Thorbjernsen, H. (2005). Intentions to use mobile services: antecedents and crossservice. Journal of the Academy of Marketing Science, 33(3), 330-346.

http://dx.doi.org/10.1177/0092070305276149

Okamuro, H. (2007). Determinants of successful R\&D cooperation in Japanese small business: The impact of organizational and contractual characteristics. Research Policy, 36(10), 1529-1544.

http://dx.doi.org/10.1016/j.respol.2006.12.008

Oliver, C. (1990). Determinants of interorganizational relationships: Integration and future directions. Academy of Management Review, 15, 241-265.

Palmer, A. (2000). Co-operation and competition: a Darwinian synthesis of relationship. European Journal of Marketing, 34, 687-704.

Rosenfeld, S. A. (1996). Does cooperation enhance competitiveness? Assessing the impacts of inter-firm collaboration. Research Policy, 25, 247-263.

Ryu Sungmin, Lee Eun-Ju, \& Lee Won Jun, (2011). A cross-cultural study of interfirm power structure and commitment: the effect of collectivism, Journal of Business \& Industrial Marketing, 26(2), 92 - 103. http://dx.doi.org/10.1108/08858621111112276

Saxton, T. (1997). The effects of partner and relationship characteristics on alliance outcomes. Academy of Management Journal, 40(2), 443-461. http://dx.doi.org/10.2307/256890

Schermerhorn, J. R., Jr. (1975). Determinant of interorganizational cooperation. Academy of Management Journal, 18(4), 846-856. http://dx.doi.org/10.2307/255382

Spekman, R. E. (1988). Strategic supplier selection: Understanding long-term buyer relationships. Business Horizons, 31, 75-81. 
Stank, Theodore P., Scott B. Keller, \& Patricia J. Daugherty (2001). Supply chain collaboration and logistical service performance. Journal of Business Logistics, 22 (1), 29-48. http://dx.doi.org/10.1002/j.2158-

1592.2001.tb00158.x

Stevenson, H. H., and J. C. Jarillo-Mossi (1990). A Paradigm of Entrepreneurship: Entrepreneurial Management. Strategic Management Journal, 11, 17-27.

Teece, D. (1977). Technology transfer by multinational firms: The resource cost of international technological transfer. Economic Journal, 87, 242-261. http://dx.doi.org/10.2307/2232084

Tran, T. B., Grafton, R. Q. and Kompas, T. (2009). Institutions matter: The case of Vietnam. The Journal of SocioEconomics, 38(1), 1-12. http://dx.doi.org/10.1016/j.socec.2008.05.012

Van Bruggen, G. H., Lilien, G. L., \& Kacker, M. (2002). Informants in organizational marketing research: Why use multiple informants and how to aggregate responses. Journal of Marketing Research, 39(4), 469-478.

http://dx.doi.org/10.1509/jmkr.39.4.469.19117

Vereecke, A., \& Muylle, S. (2006). Performance improvement through supply chain collaboration in Europe. International Journal of Operations \& Production Management, 26(1), 1176-1198.

Vo Tri Thanh \& Le Xuan Sang (2004). Developing financial market in Vietnam: current situations, issues and policy recommendations. Finance Publishing House: Ha Noi (Vietnam).

Zhang, Bin \& Wang, Zhaohua (2014). Inter-firm collaborations on carbon emission reduction within industrial chains in China: Practices, drivers and effects on firm's performances. Energy Economics, 42, 115-131. http://dx.doi.org/10.1016/j.eneco.2013.12.006 